\title{
Portuguese language teaching during the COVID-19 pandemic: a new look at the educational and evaluative methodologies employed in a remote context
}

\author{
Tuca Henrique Verçosa Carneiro de Andrade ${ }^{1 *}$; Eduarda Albuquerque de Moura ${ }^{2}$; Vinícius \\ Albuquerque de Souza ${ }^{3}$, Ione Teresinha Oliveira Leitão ${ }^{4}$
}

1 Graduated in History from UFPE and master's degree in Education of the Graduate Program in Education at UFPE.

2 Bachelor's degree in Letters/Portuguese the Federal University of Pernambuco UFPE.

3 Undergraduate degree in Letters/Portuguese the Federal University of Pernambuco UFPE.

4 Master's degree in education from the Ibero-American University Foundation - FUNIBER.

E-mail adresses: tucavercosa@hotmail.com (Tuca Henrique Verçosa Carneiro de Andrade), eduardaalbu@hotmail.com (Eduarda Albuquerque de Moura), viniciussouza.brasil@gmail.com (Vinícius Albuquerque de Souza), ione.teresinhal@gmail.com (Ione Teresinha Oliveira Leitão).

${ }^{*}$ Corresponding author

\section{To cite this article:}

Andrade, T.H.V.C.; Moura, E.A.; Souza, V.A.; Leitão, I.T.O. Portuguese language teaching during the COVID-19 pandemic: a new look at the educational and evaluative methodologies employed in a remote context. International Journal of Sciences. Vol. 2, No. 3, 2021, pp.76-82. ISSN 2763-5392.

Received: 10 15, 2021; Accepted: 10 16, 2021; Published: 11 03, 2021

\begin{abstract}
Covid-19 soon spread around the world, being elevated to pandemic status in March 2020 by the World Health Organization (WHO) and, in the same month, had its first case registered in Brazil. Considering the high rate of transmissibility and the lack of effective treatments against the disease, the only really efficient measure of virus control, for now, was to keep the population in quarantine. The present work aims to analyze the educational and evaluative methodologies used in a remote context in Portuguese language teaching during the COVID-19 pandemic. We had a scenario of educational crisis, considering that the majority of students, discouraged, did not attend classes assiduously, in addition to low participation in synchronous classes - which resulted in more lectures than dialogic classes. Regarding asynchronous activities, we found that a considerable portion did not do them and, in evaluative contexts, we have repeatedly witnessed cases of queue, in which we attribute to the fact that teachers did not reinvent their evaluative activities in an attempt to implement in remote teaching the same style of proof implemented in the classroom teaching.
\end{abstract}

Keywords: Remote teaching; Evaluation; Methodology; Literacy.

\section{Introduction}

In December 2019, China recorded the first cases of a respiratory virus, hitherto unknown, which, according to Souza e Silva et al. (2020), would become responsible for the biggest health crisis of the 21 st century. Covid-19 soon spread around the world, being elevated to pandemic status in March 2020 by the World Health Organization (WHO) and, in the same month, had its first case registered in Brazil.

Considering the high rate of transmissibility and the lack of effective treatments against the disease, the only really efficient measure of virus control, for now, was to keep the population in quarantine. This measure led to the closure of shops, leisure spaces and educational institutions, keeping open only essential services - such as supermarkets, pharmacies, bakeries and hospitals - and it is mandatory to use masks for entry into such establishments (MOREIRA2020).

In this context, we saw a chaotic scenario in Brazilian education, since there was no alternative but the implementation of the return to classes in the remote modality, surprising students and teachers who were not accustomed and, above all, prepared for this new teaching model. That said, it is worth clarifying that remote teaching and distance learning (DISTANCE) are teaching modalities with different 
methodologies, as explained by Mendonça (2020), which comments that:

In $\mathrm{EAD}$, there is a principle of working with the autonomy of the learner, which is requested for him to perform the independent/self-directed and flexible study, that is, when the EAD arises, it has to account for the difficulties of the public who are accustomed to sharing the same time and space in face-to-face pedagogical activities. [...] Obviously, in remote emergency education, there is also a need to break boundaries of space-time, but this is not always tied to investment in the autonomy of the apprentice and in independent and flexible study. (MENDONÇA, 2020).

In addition, it is necessary to emphasize that the DISTANCE has tools and methodologies that enable the study of the student even without the presence of a mediator, whereas in remote education such autonomy is not necessarily promoted, being, in many cases, indispensable the intervention of the educator. Another problem raised is the type of training of the professional, since the EAD has professionals trained and specialized in the area, accustomed to prepare and record classes especially for this model (OLIVEIRA; DOS SANTOS, 2020). And remote teaching was a methodology adopted in an emergency context, in which several teachers had to learn how to use digital tools both to prepare (and adapt) classes and to govern them (MENDONÇA, 2020).

While it is a fact that, with the resurgence of the number of Cases of Covid-19 in Brazil added to the lack of vaccination on a largescale, online teaching will still be a reality for a considerable period of time, causing education professionals to reinvent themselves and seek alternatives to resolve the pedagogical impact caused by the pandemic (MOREIRA2020). Having said that, we perceive this scenario as an opportunity, through observation of classes, to analyze and problematize remote pedagogical practices, as well as to point out what could be improved in terms of educational approach and, above all, in terms of evaluative activities. To this end, we will focus, primarily, on Soares's literacy concepts (2004); on the language and language of Marcuschi and Dionysus (2007); and the evaluative proposals of Furtado (2016).

The present work aims to analyze the educational and evaluative methodologies used in a remote context in Portuguese language teaching during the Covid-19 pandemic.

\section{Methodology}

We develop our field activities in two institutions: The School of Reference in Elementary and Middle School Governador Barbosa Lima, school of the state network, located in Recife - PE and the Municipal School Prof. ${ }^{\text {a }}$ Gilvanete Vieira Guedes, school of the municipal network, located in Vitória de Santo Antão - PE. Such schools were selected because they met the criterion of being in a totally remote or hybrid regime (i.e., some classroom and other remote subjects). The observation period lasted from May 2021 to August 2021 and was supported by two supervising teachers, one for each institution. In order to preserve the identity of those involved, we will not reveal the names of teachers, students or others involved. The project submitted to the ethics committee and accepted with CAAE: 52606021.5.0000.9227.

\section{Results and Discussion}

\section{1. Reference school "Governor Barbosa Lima"}

The field period at the Reference School Gov. Barbosa Lima was held between June and August 2021 and the class chosen for observation was the 1st year D of high school, and the classes organized with a weekly $2 \mathrm{~h}$ synchronous workload, through the Google Meet platform, and 4h asynchronous weekly, which took place mainly through Google Classroom, in which students and teachers have an institutional google account. During the observation period, we followed the performance of two residents of the Area of Letters Portuguese of the Federal University of Pernambuco (UFPE), under the supervision of the full professor. In the virtual classroom, posts of subjects and activities related to subjects that were being addressed in synchronous classes were posted weekly.

At first, regarding the frequency of students, we noticed low attendance in the classes on the part of these classes and, those who followed, for the most part, were not willing to participate actively, except, sporadically, by chat, contrasting with the intense encouragement on the part of teachers and the development of strategies that sought a more active profile of students in the classroom. In this sense, during the class, there were moments of fluidity breakdown of the subjects worked, since the lack of interaction on the part of the students leaves a boring atmosphere that, unfortunately, interferes in the motivation and efforts of the educators.

An interesting fact to be seen is that some students did not position themselves in the chat for fear of making grammatical and spelling mistakes, characterizing a case of low linguistic self-esteem from a normative view of the language that is disseminated in various media and even in schools. In view of the problem, the residents, together with the teacher, dedicated some classes to discuss about conceptions of language in the classroom, highlighting the notion of language as an instrument of communication and interaction, elucidating that the grammatical "errors" made by the students are not errors, but rather a variation of the language, making it necessary to understand that the language is shaped from the context and that, through it, we adapt our language, which is why, in certain situations, we must write and speak in a specific way.

In view of this, we found that both residents and the supervising teacher treat language as a socio-historical symbolic practice, a form of action between subjects and how a condition of these subjects to constitute subjects, in addition to sharing the notion that it is "conceived differently to each 
social and historical moment, evidencing its dynamic character in the social environment." (FUZA et al., 2011, p. 479). Thus, we highlight the theoretical assumptions that encompass the conception of language as a mechanism of interaction, in which the subjects are seen as social agents and an indispensable part of the discourse. In this conception of language, it is understood that the basic concern of the teaching of the mother tongue is to lead the student not only to the knowledge of the grammar of his language, but, above all, to the development of the ability to reflect, critically, on the world around him and, in particular, on the use of language as an instrument of social interaction (FUZA et al., 2011, p. 490).

This action was well articulated in the classroom, since the discussions about the subjects worked always took into account everyday themes in the reality of the students, besides enabling contact with texts that are part of their daily lives, in a participatory and dialogical way, despite the communicative impasses. Therefore, we highlight that in the observed classes the text was worked as a place of interaction and exchange of information, between the teacher and student, and the meanings of the texts constructed in this interaction. Moreover, added to these family themes, the sharp effort in working with students points out their critical view of the texts read, corroborating the ideas of multiliteracies previously introduced here by Marcuschi and Dionysus (2007) and Soares (2004).

Regarding the subjects addressed, texts from the journalistic sphere were worked, such as news and reporting, in line with the graphic, infographic and advertising genres. For the work with these genres, we observed that the resident resorted to mechanisms that brought the students closer to the class, for example, we have the gamification of the content. However, although past activities include structural elements and pertinent to these genres, the exercise of textual production was left aside. Even in the evaluation activities, made through Google Forms, the questions dealt with more formal and structural aspects of the genres studied, without making room for the writing axis to be worked efficiently.

In this context of evaluation, we consider it pertinent to report a curious event that we witnessed during our observation, in which three students were accused of plagiarism, for delivering the same answer in a question of an activity, which led the teacher, together with the residents, to discuss what should be done about it, since the situation was quite delicate, for the answer had not indeed been a contagion, but a work together. Apparently, the three students are enrolled in a kind of school reinforcement and took the activity to be done in group, resulting in an identical response for the three students in question. It is known that, in the remote modality, there is no way to control or intervene possible queue schemes between students and, in view of this, we believe that perhaps the activities spent in groups are more profitable, because the team members will discuss the activity among themselves and, consequently, learn the subject. After all, remote education is an atypical circumstance and, therefore, a perfect circumstance for the reinvention of methodologies, showing it to be wrong to insist on practices implemented in face-to-face teaching. That said, although the queue situation reported here should not be praised, we argue that simply punishing is also not the best option. Fortunately, the decision of the teacher and the residents was not to punish, but to elucidate to the students that the attitude was unfair towards the other students and that this should not be repeated, dialoguing with the perspective of Luckesi (2000), since "evaluating a student implies, first of all, welcome him in his being and in his way of being, as it stands, to, from there, decide what to do".

Regarding the fulfillment of deadlines and deliveries of activities, we detected that a small number of students performed the delivery of asynchronous activities and that most also did not perform the evaluation activities. Therefore, this situation became worrisome, because teachers and residents were unaware of their student body, since, in addition to the absence in the classroom, many did not do any activity - although in the class council was discussed about these aspects and the school was ready to carry out an active search, that is, to contact the student's guardians in order to understand their absence and request that they participate in classes and activities Proposals. In large part, this picture stems from the lack of conditions and resources (such as electronic devices and internet access) so that they can regularly attend activities.

Moreover, it is noticeable that the teacher and residents sought feedback from the students at all times in order to improve their pedagogical practices. This is evident when they mobilized the realization of a culmination activity, where we sought a return and reflection of the activities developed and remote teaching. When asked about the main problems for frequency and commitment in this teaching model, students constantly reported problems regarding anxiety, insomnia, loss of focus, sleep during classes, accumulation of activities, agitated and noisy space in their homes, dividing themselves between study and work, among other issues. In addition, when asked about the positive and negative aspects of LP classes, the students were slow to answer and argued that they did not know what to report, in the few answers some point out that the presence of few students in online classes is a negative aspect and highlight that they like Portuguese language classes. On this occasion, the teachers spoke about their considerations and sensations in relation to the work being developed, while trying to motivate and make the students aware of their commitment and role in the classes, for this they were shown and discussed some videos and short films.

Finally, we highlight that the communication between student-teacher was also through a group on the social network WhatsApp, intended for transmission of reports, access link to classes, posting of activities and materials used in the classroom. The students also, for the most part, always justified the reasons for their absence in the classroom and attest to the performance of past activities. Therefore, the social network proved to be a fundamental tool in this remote model.

\subsection{Municipal School "Professora Gilvanete Vieira Guedes"}


The observation period at the Municipal School Prof. ${ }^{a}$ Gilvanete Vieira Guedes, in Vitória de Santo Antão, Pernambuco, was held between May and September 2021, with two ninth-grade classes that, due to the remote period, began to have joint classes. Through the Google Meet platform, the two classes together took Portuguese classes with a synchronous2-hour workload and 4asynchronous weekly hours. We also count on the assistance of class groups in WhatsApp, so that teacher-student communication would be more dynamic.

The first difficulty found in this school was the low frequency of the students, since some of them, without access to the cell phone, had to attend classes through their parents' devices, which were not always available at home at the agreed times. The combination of the ninth-year class, which culminated in a class of about forty students, resulted in classes with a maximum of ten students present. To solve the problem, the school's coordination contacted the students and their guardians in order to resolve connectivity issues. The alternative found was to send the activities performed in the classroom periodically in a written way to those students whose internet access was, in fact, limited. Still, they were left without access to the class and without communication with the teacher.

The low participation of those who attended the classes was another difficulty of the remote model. The cameras are always closed and only two or three students open the microphone to speak, answer questions or ask questions, weakening the student-teacher relationship, given that this learning model culminates in a purely exhibition class - which also limits the opportunities to propose group activities among the students themselves, suddenly inserted in a completely different context from what they were accustomed to.

Activity deadlines also had to be frequently extended because of the low responsiveness of the class, or because of its low attendance on telephone devices, which many are still learning to use in the school context. We therefore have a context of near evasion, where students open computers, but do not actually attend classes, or at least the teacher has no way of ensuring that they attend. Moreover, the parents' search to solve this problem was ineffective, since most of them work during the day and leave their children at home or, in some cases, simply did not respond to attempts to contact the school, noting that parental involvement in the children's education is a difficulty factor in the Gilvanete.

Literacy regarding the use of technology is another problem for students. We use here the term "literacy" in order to have access and know how to use a certain technology. For Soares (2006), literacy is a matter of making use of practices and points out that digital literacy syntagma is used to refer to the issue of reading and writing practice made possible by the computer and the Internet. Thus, as stated earlier, many students have never had access to this technology, especially those enrolled in public school, without computer access and without familiarity with the platforms introduced, such as Google Forms, Google Meet or even WordDocs - which made it seriously difficult to perform activities, especially the evaluative ones.
Having said that, with regard to the evaluation, we verified that the remote modality created an unexplored place for both teachers and students. In the face-to-face mode, the parameters of the evaluation are, according to Hadji (1994), based on the valorization of the acquisition of content as a product of thought (facts, concepts, laws) and in the domain of capacities (intellectual or cognitive operations, mental activities that allow an adequate response toa given situation), therefore, this type of opinion excludes the affective parameters of the evaluation. It is through the summative test that we come to a result, however, prevented from evaluating the causes of the student's failure.

The summative evaluation is also one that needs to be "monitored" by the teacher, because we know that appropriate answers to a given situation, as well as concepts and facts are data available on any internet network or digital platform. In the remote model, there is a difficulty in preventing the student from doing research in the network while answering an evaluation and, in addition to this, the school did not offer viable alternatives to this specific problem, which is one of the most severe.

The issue of evaluation also created a "makeup" in the learning system. Without having tools to evaluate students fairly and affectively, teachers resort to traditional assessments, which, as stated earlier, is a flawed model for the remote scope, easily manipulated by the students themselves. In this sense, although the scores were high, we can infer that the content absorption was low, given that the demand to answer doubts and perform asynchronous activities was low.

We know that changing such practices would mean a profound change in the structure of the school, which follows with a traditional view of evaluation. However, it is interesting to take into account that the remote context itself is a profound change in the way students practice school, in the act of studying, as well as in the way the teacher teaches and interacts.

In the second half of the 20thcentury, some countries, whose system of language adopted by the native language is alphabetical, realized the relevance of turning their gaze to discussions about the areas of education and languages. In this context, a debate on literacy methodologies began and it was noted that there is a difference between being literate and being able to participate in various social activities that involve reading and writing.

Therefore, the term "literacy" is used for all that activity that involves social practices of the language in the context of reading and writing. The term is derived from English, "literacy", and the same has been re-signifies, since, in English, the word is used as equivalent to "literacy". However, as Soares (2004) points out, literacy and literacy are different things, however, interdependent.

Dissociating literacy and literacy is a mistake because [...] the entry of the child (and also the illiterate adult) into the world of writing occurs simultaneously through these two processes: by the acquisition of the conventional writing system - literacy - and by the development of skills of use of this system in reading and writing activities, in social practices involving written language - literacy. 
(SOARES, 2004, p. 14).

Thus, the author points out how the methodologies currently adopted for the teaching of the alphabetic writing system should be aligned with the theories related to the cognitive and linguistic development of the child, so that the literacy process does not sum up literacy, but also worries in lettering the child so that, by alphabetizing it, he has the ability to participate in social practices of reading and writing.

Thus, Soares (2020) coins the term "alphaletrar", which is based on the concept of multiliteracies, initially presented by Street and Street (2014), and understands that teaching and the literacy process should consider the insertion of the individual in the various socio-interactive areas of reading and writing, meeting the needs of comprehension of texts. After all, language learning is broad and is not based solely on the study of graphic code and its phonetic relationships, even if it is not successful, also, without the explicit demonstration of such codes, as the author points out:

[...] defending the specificity of the literacy process does not mean deterred it from the literacy process [...], however, what unfortunately seems to be occurring today is that the perception that one begins to have, that if children are being, in a way, literate in school, they are not being literate, seems to be leading to the solution of a return to literacy as an autonomous process (SOARES, 2004, p. 11).

Added to the notion of multiliteracies, it is interesting that the pedagogical practices of teachers are aligned with their conception of language. Throughout history, much has been discussed about what is language and what its function is, with Greek philosophers being the ones who stood out most for reflecting on such issues, divided into two main currents: naturalists and conventionalists. The first group was composed of those who defended the thesis that language has a spiritual bond with reality, with a relationship between form (word) and elements of nature (meaning), making it possible to understand reality by rescuing the linguistic sign and its corresponding element of nature. On the other hand, the second group, the conventionalists, argued that language is merely a means of communication, refuting that there would be some kind of relationship between form and meaning, being its use purely arbitrary and established from convention and tradition.

The debate regarding the function of language and the understanding of its use in society extends to the day, however, with a new outfit: functionalists and formalists. The formalist aspect, adept at "geractive" Grammar, elaborated by theoretician Noam Chomsky, assumes a more structuralist and normative position on language, adopting a bipartite model in which "[...] linguistic knowledge includes two basic "ingredients": a lexicon, understood as a set of items that must be learned and memorized individually, and a grammar, defined as a set of general rules of simple combination and semantic interpretation" (PINHEIRO, 2015, p. 163).
The functionalist aspect, however, understands that the main function of language is, as Heine (1997) elucidates, to express meaning, being the language a historical and cultural product, and its use motivated by the various socio communicative situations which we insert on a daily basis. That said, as opposed to the geractive theory, the speaker is not at the service of syntax, but the opposite, with syntax - and in turn the language - at the service of the speaker. Thus, linguistic variations are external to the structure of the language and its occurrences are the result of convention and linguistic "situationality", besides being able to, to some extent, reflect the structure of the experience. In this sense, here we adopt the perspective of language as a set of discursive practices that are inserted in our social practices, not being resuming to its structure or system, but also taking into account the counteractive scope.

Therefore, if, as Marcuschi and Dionysius postulate (2007), we understand language as a historical, social, variable and heterogeneous phenomenon, and having studied about the importance of methodologies that contemplate multiliteracies in the classroom, the Curricular Parameters of Pernambuco (2013) highlight the need to prepare the student so that he understands how to use his senses (tact, hearing and vision) for the interpretation of everyday linguistic resources - such as gestures, intonations, colors and sizes - so that, in this way, the student has full conditions to insert and participate in the various types of literacy, being, therefore, an education that stimulates multiliteracies and multimodalities.

Such education can be achieved through the insertion and contextualization of textual genres in Portuguese language teaching methodologies, where it is necessary to guide them not only to differentiate textual genres, but to position themselves before them, preferably with theoretical basis. That said, this student should be able to infer information and justify it according to the context in which the text is inserted, in addition to critically analyzing textual intentions.

Theaterwide regard to the evaluation process and considering that the teacher is, as Furtado (2016) raises, inherently a political being, it is necessary to highlight that the methodology adopted in a given evaluation is also a political choice.

A pedagogical practice guided by liberating education is guided by a critical analysis of social reality and is implicitly supported by sociopolitical purposes of education. This means that the teacher must understand that education is not neutral and assume the political nature of the educational act. This understanding is reflected in the attitude of the educator who, by breaking with the authoritarian relationship between teacherstudents, seeks to build a relationship of horizontality in the practice of dialogicity (FURTADO, 2016, p. 3-4).

Now, when choosing an evaluation style, the teacher is skewing his work, because different types of evaluation can follow different theoretical lines. For example, if the teacher prefers to verify the performance of his students through a 
6 Andrade, T.H.V.C.; Moura, E.A.; Souza, V.A.; Leitão, I.T.O. Portuguese language teaching during the COVID-19 pandemic: a new look at the educational and evaluative methodologies employed in a remote context...

multiple-choice test, it can be inferred that he has no interest in stimulating reflection and critical thinking in his students, treating teaching-learning as something vertical and based on "decoreba" (LUCKESI, 2000).

This could also perpetuate the idea that the teacher is above the student, since the teacher does not surrender to the productive errors of the students and, consequently, does not work on them. Reducing the error to simply a mistake is mistaken and unproductive from a methodological point of view, as Furtado points out.

The perfectionist view constructed from the Cartesian paradigm made us believe that where there is error there is no right and vice versa [...] and the school, institution responsible for formalizing the teaching-learning process [...] structured itself consistent with the beliefs and values that segregate the error from the context of learning. [...] The error is the result of the teacher's analysis of the students' answers, in terms of right or wrong, which reveals how much the pedagogy of the answer is still worship able, which, in turn, expresses how much we are still, as Paulo Freire defined, in the era of banking education. (FURTADO, 2016, p. 1).

That said, considering that, from Xavier's perspective (2005), the students are digital natives, once they were born in a technological environment, Information and Communication Technologies (ICT) proved essential not only to evaluate students, but also to govern classes in a remote emergency context, making room for the insertion of digital genres - such as Google forms, podcasts, YouTube videos, news or reports extracted from various websites. With this, multiliteracies are increasingly stimulated, understanding that the literacy of the letter, as Rojo (2017) attests, is no longer sufficient to account for the new reading and writing practices imposed by modern society.

However, in view of the current circumstances and the uncertainty of $100 \%$ face-to-face return of educational activities, it is necessary to use methodologies that seek to fill the gaps resulting from remote education. After all, even though there is too much commitment of the pedagogical team to provide students with transformative educational experiences in teaching mediated by new technologies, it is also known that, unfortunately, there is no way to deliberate on the contents with the same depth as in traditional face-toface teaching, given the lack of sufficient workload and wide participation of students - topics that will be discussed in subsequent topics.

Having said that, for the present work, we selected two schools with the objective of turning our gaze to the way that educators mediated their remote classes, anchoring our analysis in the theoretical precepts introduced here in literacy; language conception; textual genres; and evaluation, observing their influence on the educational and citizen formation of students, with classes that stimulate them and provoke reflection, since knowledge should not be other, even if the current conjuncture is atypical.

\section{Conclusions}

From this observation experience, we conclude that this activity is of fundamental importance for thinking about teaching practice in mother tongue teaching, because, as teachers, we can, from the insertion in virtual classroom spaces, perceive the fine line between the theoreticalmethodological knowledge seized in the academy in line with the practical approach.

Moreover, although we have carried out the field period in an atypical context, this aspect does not mischaracterize the reflective and learning impact, since we found an incalculable balance of reflections and essential learning to observe and question education, school, students, teachers, residents, the curricular component of Portuguese language and ourselves on the act of educating. Tied to this, as the most striking element of this experience remotely, we explained the challenges of teaching practice in LP in a totally digital and technological space, which, despite the use of technologies as a teaching tool is not a recent discussion, caught everyone and all off guard.

\section{References}

[1] DIONÍSIO, A.; MARCUSCHI, L. A. (orgs.). Fala e Escrita. Belo Horizonte: Autêntica: 2007.

[2] FURTADO, Júlio. A pedagogia do erro. 2016.

[3] FUZA, Ângela; OHUSCHI, Márcia; MENEGASSI, Renilson. Concepções de linguagem e o ensino de leitura em língua materna. In: Linguagem e ensino, Pelotas, v.14, n.2, p. 479-501, jul/dez. 2011.

[4] HADJI, Charles (1994). Avaliação: as Regras do Jogo. Porto: Porto Editora.

[5] HEINE, Bernd. Cognitive foundations of grammar. Oxford University Press, 1997.

[6] LUCKESI, Cipriano. O que é mesmo o ato de avaliar a aprendizagem? On-line Pátio. Porto Alegre: ARTMED. Ano 3, n. 12 fev./abr. 2000.

[7] MENDONÇA, Márcia. Entrevista especial VIII - Márcia Mendonça (Unicamp). Entrevista concedida à Lara Albino; Neil Franco; Nívea Rohling e Rafael Alves. O consoante, 2020.2 Disponível em: http://oconsoante.com.br/2020/12/03/entrevistaespecial-viii/

[8] MOREIRA, J. António; HENRIQUES, Susana; BARROS, Daniela Melaré Vieira. Transitando de um ensino remoto emergencial para uma educação digital em rede, em tempos de pandemia. Dialogia, p. 351-364, 2020 .

[9] OLIVEIRA, Francisco Ariclene; DOS SANTOS, Ana Maria Sampaio. Construção do Conhecimento na Modalidade de Educação a Distância: Descortinando as Potencialidades da EaD no Brasil. EaD em Foco, v. 10, n. 1,2020 .

[10] PINHEIRO, Diogo. Sintaxe construcionista. In: OTHERO, Gabriel de Ávila; KENNEDY, Eduardo 
(orgs.). Sintaxe, sintaxes: uma introdução. São Paulo Contexto, 2015.

[11] ROJO, Roxane. Entre plataformas, odas e protótipos: novos letramentos em tempo de web2. Revista The ESPecialist: Descrição, Ensino e Aprendizagem, v. 38, $\mathrm{n}^{\circ}$ 1.

[12] SOARES, Magda. Alfaletrar: toda criança pode aprender a ler e a escrever. São Paulo: Contexto, 2020.

[13] . Letramento e Alfabetização as muitas facetas. Revista Brasileira de Educação, 2004.

[14] Letramento: um tema em três gêneros. 2 ed. 11 reimpr. Belo Horizonte: Autêntica, 2006, 128p.

[15] . Novas práticas de leitura e escrita: letramento na cibercultura. Educação e Sociedade: Campinas, vol.23, n.81, p.143-160, dez. 2002.

[16] STREET, Brian. Letramento sociais: Abordagens críticas do letramento no desenvolvimento, na etnografia e na educação. Tradução Marcos Bagno. São Paulo: Parábola, 2014.

[17] XAVIER, Antônio Carlos. Reflexões em torno da escrita nos novos gêneros digitais na internet. 2005 Disponível em

https://periodicos.ufpe.br/revistas/INV/article/view/148 4. 